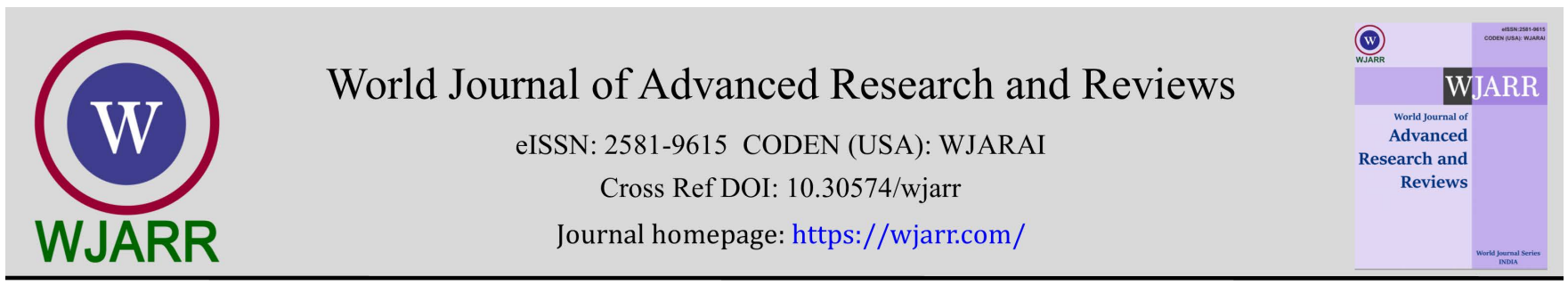

(REview ARTICLE)

\title{
Kayakalpam (Rejuvenative) herbs: An immunomodulators in Siddha system of medicine: A scientific review
}

\author{
Carl Lewis John *, Leo Praveen Chelliah and Guru Prasad Chelliah
}

Agasthi Siddha Private Limited, Coimbatore, Tamilnadu, India.

World Journal of Advanced Research and Reviews, 2022, 13(02), 505-510

Publication history: Received on 15 January 2022; revised on 24 February 2022; accepted on 26 February 2022

Article DOI: https://doi.org/10.30574/wjarr.2022.13.2.0167

\begin{abstract}
Background: Kayakalpam (Rejuvenative) medicine is one of the prime treatment technique in the Siddha system of medicine. Kayakalpam has potential to heal, rejuvenate and balance the vatham, pitham and kapam (tri-dhosas) which make the body and mind to attain its stability. Several studies have been done on Kayakalpam medicines, but, this review article states about few Kayakalpam herbs, their chemical constituents, pharmacological activities and its immunomodulatory mechanism towards the prevention and management of non-communicable diseases and several other diseases.
\end{abstract}

Methods: A literature review was conducted using the following scientific databases: PubMed, Research gate, Science Direct, Google scholar, Ayurvedic Pharmacopoeia of India and Siddha Pharmacopoeia of India. The aim was to identify published data on traditionally used medicinal plant for rejuvenation and immuno-modulatory effect. From that, few Kayakalpam herbs have been chosen which has been mentioned in the Siddha literature and reviewed its nature.

Conclusion: This literature review reveals the potential effect of Kayakalpam herbs and its nature. Beyond any doubt it will help in prevention and management of non-communicable diseases and several other diseases.

Keywords: Kayakalpam; Siddha System of Medicine; Rejuvenation; Immuno-modulator; Kayakalpam herbs; noncommunicable diseases

\section{Introduction}

According to the World Health Organization (WHO), about three-quarters of the world population rely upon traditional remedies (mainly herbs) for the health care of its people. In fact, herbs and/or plants are the oldest friends of mankind. They not only provided food and shelter, but also served to cure different ailments. Traditional medicine all over the world is currently being revalued through extensive research activity on various plant species and their therapeutic properties [1]. Non-Communicable Diseases (NCDs) are the leading cause for morbidity and mortality worldwide, with three-fourth of deaths occurring in the low and middle-income countries like India [2]. Between the years 1990 and 2016, disease burden in India due to NCDs increased from 48\% to 75\%. Currently, three out of the top five causes for morbidity and mortality in the country are NCDs [3]. Rising burden of NCDs is due to rapid urbanization and social development occurring in the country over the past two decades. The change occurring in social structures transforms lifestyles of populations that are mainly characterized by increased adaptation of unhealthy diet, physical inactivity and tobacco use [2]. These modifiable risk factors precede the development of metabolic risk factors and then progress to NCDs in populations [4]. Kayakalpam is one of the unique therapeutic formulations in Siddha system advocated for rejuvenation, longevity and elimination of disease causing factors. The Siddhars had primly focused on their spiritual well-being through this Kayakalpam. In recent years lifestyle modification is one of the main causes of many diseases

\footnotetext{
${ }^{*}$ Corresponding author: Carl Lewis John

Agasthi Siddha Private Limited, Coimbatore, Tamilnadu, India.

Copyright $(2022$ Author(s) retain the copyright of this article. This article is published under the terms of the Creative Commons Attribution Liscense 4.0.
} 
including cancer. So it necessitates to turn towards Kayakalpam herbs which are rich in natural source of antioxidants [5]. Production of free radicals results in oxidative stress due to damage of Deoxyribonucleic acid (DNA), proteins, lipids and has been suggested to be the cause of most of the serious human diseases [6]. This article is a review of Kayakalpam herbs as mentioned in Siddha literature and scientific exploration of its potential immuno-modulatory activity towards the prevention and management of non-communicable diseases and several other diseases.

\section{Material and methods}

A literature search was conducted using the scientific databases including PubMed, Research gate, Science Direct, Google Scholar, Ayurvedic Pharmacopoeia of India and Siddha Pharmacopoeia of India. The aim was to identify published data on traditionally used medicinal plant for rejuvenation and immuno-modulatory effect. The search terms used were "rejuvenation and plants", "traditional plants", "medicinal plants and immuno-modulatory effect" and "mechanism of anti-oxidant action" and many herbs have been described and their possible mechanism of anti-diabetic, anti-cancerous, anti-oxidant, anti-inflammatory, anti-microbial, hepato-protective, and immuno-modulator action has been mentioned. From that, few Kayakalpam herbs have been chosen which has been mentioned in the Siddha literature.

\subsection{Brief history of Siddha System of Medicine (SSM)}

An ancient system of medicine prevalent in Tamil Nadu, South India. The word Siddha comes from the Tamil word for perfection. Those who attained an intellectual level of perfection were called Siddhars. Siddha drugs arrest the degeneration of cells in the body. The Siddha system advocates control of breathing and diet. Meditation and yoga are part of the system [7]. The sages of south India, who practiced tantrism contributed and established a medical system to serve the humanity in general and their own society in particular. Those sages were called as Siddhars and the medical system used by them is called as SSM. Though the creation of this system is ascribed to Lord Siva, the creator of the universe, the sage Agasthiyar is considered as a father figure of the Siddha medical system. He is also considered to be the father figure of the Tamil language and culture [8]. SSM has been closely identified with Tamil civilization too [9].

\subsection{KayaKalpam}

The word Kayakalpam means (kayam-body,kalpam-able, competent) to make our body competent and youthful. It is a unique discipline of Siddha system of medicine that addresses the methods and drugs for longevity and enhancement of innate health. They can be divided into kalpa medicines, kalpa practices of life style and kalpa diet. In this science 108 herbs and herbo-mineral combinations are recommended for normal individuals to boost immunity, to promote general health, for prevention of diseases (pothu karpam) and also for restoration of health from specific type diseases (sirappu karpam). Current science confirms the health benefits of many Kayakalpam drugs are due to their anti-oxidant property [10].

\subsection{Immuno-modulation by Medicinal Plants}

Plant extracts used in traditional therapy are being reviewed for their chemo protective and Immuno-modulatory activities. Immuno-modulators are biological response modifiers; exert their antitumor effects by improving host defense mechanisms against the tumor. They have a direct anti-proliferative effect on tumor cells and also enhance the ability of the host to tolerate damage by toxic chemicals that may be used to destroy cancer [11]. Immuno-modulatory therapy could provide an alternative to conventional chemotherapy for a variety of diseased conditions, especially when host's defense mechanisms have to be activated under the conditions of impaired immune responsiveness or when a selective immunosuppression has to be induced in a situation, like inflammatory diseases, auto-immune disorders and organ/bone marrow transplantation [12]. Anti-oxidants are molecules that interact with free radicals, neutralize the electrical charge and terminate the chain reaction. Anti-oxidants also fight against ROS (Reactive oxygen species) and protect the cells from their damaging effects. Therefore the production of ROS during cellular metabolism is balanced through their removal by anti-oxidants. Any condition leading to increased levels of ROS results in oxidative stress, which promotes a large number of human diseases including cancer. Therefore, anti-oxidants may be regarded as potential anti-carcinogens and they are classified according to their mechanism of action as anti-oxidants which break or interrupt the steps involved in the production of free radicals and also as anti-oxidants which prevent the formation of oxygen free radicals by several actions. Since Synthetic anti-oxidants have possibility of promoting carcinogenesis natural anti-oxidants from herbal sources are considered as superior preferably [10]. A number of Indian medicinal plants and various Kayakalpam herbs have been claimed to possess immuno-modulatory activity. Therefore, this article comprises some of the common Kayakalpam herbs and their immunomodulatory actions which is reconfirmed by scientific parameters. 


\subsection{Kayakalpam Herbs as Immuno-modulator}

\subsubsection{Aloe barbadensis Mill}

Aloe barbadensis Mill (Siddha/Tamil name - Katrazhai) is a very well-known medicinal plant and it belongs to the family Asphodelaceae. It grows in arid climates and widely distributed in Africa and other arid areas. It is claimed that Aloe barbadensis has wound and burn healing properties and also possess a strong anti-inflammatory and immunomodulatory effects. The bioactive components of Aloe barbadensis have aid the treatment of gastrointestinal diseases, i.e., inflammations, gastric, duodenal and intestinal ulcers. It also aids lipid and carbohydrate metabolism, which helps to maintain normal blood sugar and cholesterol levels as well as normal body weight. Due to aloin, the daily intake of aloe juice should not exceed 30-40 ml, because excessive consumption may not only have a strong laxative effect but also toxic effects. [13-16].

\section{Chemical Constituents}

Flavonoids, terpenoids, lectins [17,18], fatty acids, anthraquinones [19], mono- and polysaccharides (pectins, hemicelluloses, glucomannan), tannins, sterols (campesterol, $\beta$-sitosterol), enzymes, salicylic acid, minerals (calcium, chromium, copper, iron, magnesium, manganese, potassium, phosphorus, sodium and zinc) and vitamins (A, C, E, $\beta$ carotene, B1, B2, B3, B6, choline, B12, folic acid) [20-23].

\section{Immunomodulatory Mechanism}

The effects of Aloe barbadensis on microcirculation and levels of TNF- $\alpha$ and IL-6 were investigated in rats after inducing burn. It was found that the amount of leukocyte adhesion was significantly reduced in the Aloe barbadensis treated burn wound rats compared to rats in the control group. It was also observed that the levels of TNF- $\alpha$ and IL- 6 reduce significantly [24]. Dihydrocoumarin derivatives (1,2) were isolated from Aloe barbadensis which exhibited immunomodulatory activity in relation to increasing the phagocytic activity and stimulating the production of superoxide anions in the oxygen respiratory burst of rat peritoneal macrophages [25].

\subsubsection{Asparagus racemosus Willd}

Asparagus racemosus Willd (Siddha/Tamil name - Thanneervittan) is a widely occurring medicinal plant belonging to the family of Liliaceae. This species is found abundantly in subtropical and tropical zones such as India, Asia, Australia and Africa. Asparagus racemosus is frequently used in siddha drug preparations as it is known to treat conditions such as ageing, to boost immunity, improve longevity, vigor, mental function. Asparagus racemosus also finds its application in curing neurological disorders, hepatopathy, tumors and dyspepsia [26]. Various therapeutic properties of root of Asparagus racemosus is well documented in ancient siddha literature. The therapeutic property is owing to the presence of various pharmacological properties such as antioxidant property, anti-inflammatory property antiseptic and antimicrobial property [27, 28]. Asparagus racemosus is recommended for prevention and treatment of gastric ulcers, dyspepsia and as a galactogogue. The Asparagus genus is considered to be of medicinal importance because of the presence of steroid saponins and sapogenins in various parts of the plant. Immunomodulating property of Asparagus racemosus has been shown to protect the rat and mice against experimental induced abdominal sepsis [30].

\section{Chemical Constituents}

Saponins (Shatavarin I-V), alkaloids, polyphenols, flavonoids, vitamin C [29].

\section{Immunomodulatory mechanism}

It shows antioxidant activity through the free radical scavenging, superoxide anion radical scavenging, hydrogen peroxide scavenging, nitric oxide scavenging, metal chelation, reduction power and inhibition of lipid peroxidation in rats [29]. Asparagus racemosus showed anti-sepsis activity by altering the function of macrophages, indicates its possible immunomodulatory property. Alcoholic extract of Asparagus racemosus has been found to enhance both, humoral and cell mediated immunity of albino mice injected with sheep red blood cells as particulate antigen. Oral administration of decoction of powdered root of Asparagus racemosus has been reported to produce leucocytosis and predominant neutrophilia along with the enhanced phagocytic activity of the macrophages and polymorphs [30]. Studies have proved the role of aqueous Asparagus racemosus root extract in protecting the gamma radiation induced damage in the liver. The antioxidant potential was well characterized against lipid peroxidation [31]. 


\subsubsection{Solanum trilobatum Linn}

Solanum trilobatum Linn (Siddha/Tamil name - Thoothuvalai) belongs to the family Solanaceae with genus Solanum native to India and is found everywhere in Tamil Nadu. It is widely used as an Indian alternative system of medicines like siddha, ayurveda, herbal medicines and natural home remedy for various conditions like stomach pain, asthma, respiratory problems, cough and cold etc., and is also used for various recipes. Solanum trilobatum is reported to cure numerous diseases viz., respiratory problems and bronchial asthma [32]. Solanum trilobatum was reported to harbour hepatoprotective activity, antimicrobial activity, larvicidal activity, antidiabetic activity, cytotoxic activity and anticancer activity. The leaves and stem of Solanum trilobatum are reported to possess anti-mitotic, anti-inflammatory and anti-ulcerogenic properties. The leaf extracts are used to increase male fertility and to cure snake poison [33]. The major alkaloids identified in the alcoholic extract from leaves and stem part of Solanum trilobatum has been shown to possess anti-mitotic and anti-microbial activity against bacteria and fungi. Biological screening of the alkaloid mixture of this plant revealed anticancer activity against certain type of cancer and its effectiveness as an adjuvant in cancer chemotherapy [34].

\section{Chemical Constituents}

Steroids, triterpenoids, sugars, reducing sugars, phenolic compounds, tannins, anthroquinone, amino acids, saponins [35]. Carbohydrates, phytosterols, flavonoids and cardiac glycosides. Alkaloides such as soladunalinidine and tomatidine(4) chemical compounds like Sobatum(1), $\beta$-solamarine, solasodine(2), solaine(3), glycoalkaloid and diosogenin(5) [36].

\section{Immunomodulatory mechanism}

Aqueous extract of leaves of Solanum trilobatum was pharmacologically validated for its immuno-modulatory properties in experimental animals. Oral administration of the extract at a dose of 100, $200 \& 400 \mathrm{mg} / \mathrm{kg}$ significantly increased in percentage neutrophil adhesion $(\mathrm{P}<0.001)$. The Delayed Type Hypersensitivity also showed a dose dependent activity $(\mathrm{P}<0.001)$. Further, a dose related increase in haemagglutination antibody titer was observed with different doses as compared to control group. Phagocytic index was significantly increased after the administration of Solanum trilobatum compared to control group $(\mathrm{P}<0.001)$. These findings suggested that the immuno-stimulatory activity of Solanum trilobatum influences by potentiating humoral as well as cellular immunity [37].

\subsubsection{Tinospora cordifolia Willd}

Tinospora cordifolia Willd (Siddha/Tamil name - Seenthil) belonging to the family of Menispermaceae. This is a perennial climber distributed throughout the tropical Indian subcontinent. It is categorized well known for its adaptogenic and immuno-modulatory activity in fighting infection. The activity of this drug appears to be due to alkaloid. It is shown to effective against various types of experimental induce infection [38]. The plant has several therapeutic properties such as jaundice, rheumatism, urinary disorder, skin diseases, diabetes, anemia, inflammation, allergic condition, anti-periodic, radioprotective properties, etc [39-41]. The root of Tinospora cordifolia is used as potent emetic and for bowel obstruction. The starch (Seenthil Sarkarai) of this plant serves a beneficial household remedy for chronic fever, relieves burning sensation, increases energy and appetite. Tinospora cordifolia is useful in the treatment of helminthiasis, heart diseases, leprosy, and rheumatoid arthritis, support the immune system, the body's resistance to infections, supports standard white blood cell structure, function, and levels [42].

\section{Chemical Constituents}

Diterpenoid furanolactone, 3- ( $\alpha 4$ - dihydroxy-3-methoxy benzyl) 4-(4-hydroxy-3- medoxybenzy1) tetra-hydrofuran, tinosporaside. tinosporide, magnoflorium, giloin, gilosterol, gilenin, columbin, chasmanthin, palmaria, tinosporin, tinosporic acid,tinosporal and amritoside A,B,C and D [43].

\section{Immunomodulatory mechanism}

Increase the total white blood cell count, bone marrow cellularity and $\alpha$-esterase positive cells enhance the macrophage activation [44]. The compounds rise to significant increases in IgG antibodies in guinea pig serum. Cordioside (TC-2), cordiofolioside A (TC-5) and cordiol (TC-7) activated macrophase with increasing incubation times [45].

\section{Conclusion}

Amongst 108 herbs in the Siddha system, examined only 4 herbs for this article. Based on their therapeutic properties, pharmacological activities, chemical constituents and immunomodulatory mechanism, this Kayakalpam (Rejuvenative) 
Herbs certainly useful in aspects of the prevention, treatment and management of NCDs. Many other questions have yet to be explored and offer the possibility of further investigation.

\section{Compliance with ethical standards}

\section{Acknowledgments}

I would like to thank my team and management for their significant assistance and support in completing this research.

\section{Disclosure of conflict of interest}

The authors declare that there is no conflict of interest.

\section{References}

[1] Dinesh Kumar, Vikrant Arya, Ranjeet Kaur, Zulfiqar Ali Bhat, Vivek Kumar Gupta, Vijender Kumar. A review of immunomodulators in the Indian traditional health care system. Journal of Microbiology, Immunology and Infection. 2012; 45: 165- 184.

[2] World Health Organization Regional Office for the Western. Global status report on noncommunicable diseases 2010 [Internet]. Geneva: World Health Organization; 2011 p. 164. Report No.: ISBN 978924 068645 8. Available from: https://www.who.int/nmh/publications/ncd report full en.pdf

[3] Indian Council of Medical Research, Public Health Foundation of India, Institute for Health Metrics And Evaluation. India: Health of the Nation's States (India State-Level Disease Burden Initiative) [Internet]. [cited 2020 May 9]. Report No.: ISBN 978-0-9976462-1-4. Available from: https://phfi.org/the-work/ research/the-india-state-level-disease-burden-initiative/

[4] World Health Organization. WHO STEPS Surveillance Manual: STEPwise Approach to Non Communicable Disease risk factors surveillance [Internet]. Geneva: World Health Organization. Jan 2017; 7-1-5.

[5] Vithyavani N et al., Kayakalpa Herbs - The Siddha Nutraceutical for the Prevention of Cancer. Int J Pharm Pharm Sci. 6(1): 99-103.

[6] Indap MM, Parab SR Evaluation of antioxidant and anticlastogenic properties of sponge Tetheya lynevrium [Linn]. Indian drugs. 9 Sep 2008; 45.

[7] Kaliyaperumal Karunamoorthi, Kaliyaperumal Jegajeevanram, Jerome Xavier, Jayaraman Vijayalakshmi, Luke Melita. Tamil traditional medicinal system - siddha: an indigenous health practice in the international perspectives. TANG Humanitas Medicine 2012; 2(2): 12.

[8] CCRAS. Central Council for Research in Ayurvedic Sciences. Siddha. 2008.

[9] Narayanaswamy V. In: Introduction to the Siddha System of Medicine. (Madras, India: Research Institute of Siddha Medicine). 1975.

[10] T Thirunarayann,Introduction to siddha medicine, Centre for traditional medicine and research. 2012; 189-192.

[11] Namrata Singh, Mukul Tailang and S.C. Mehta. A Review on Herbal Plants as Immunomodulators. IJPSR. 2016; 7(9): 3602-3610.

[12] Upadhyay S.N. Plant products as immune response modulators. In: Proceedings of the International ayurveda conference, Sanjay Gandhi post graduate institute of medical sciences, Lucknow. 1997, pp. 10.

[13] Surjushe A, Vasani R, Saple D. Aloe vera: a short review. Indian J Dermatol. 2008; 53: 163-166.

[14] Sahu PK, Giri DD, Singh R, et al. Therapeutic and medicinal uses of Aloe vera: a review. Pharmacol Amp Pharm. 2013; 4: 599-610.

[15] Duansak D, Somboonwong J \& Patumraj S, Effects of Aloe vera on leukocyte adhesion and TNF- $\alpha$ and IL-6 levels in burn wounded rats, Clin Hemorheol Micro. 2003; 29: 239- 246.

[16] Zhang X, Wang H, Song Y, Nie L, Wang L, Liu B, Shen P \& Liu Y, Isolation, structure elucidation, antioxidative and immunomodulatory properties of two novel dihydrocoumarins from Aloe vera, Bioorg Med Chem Let. 2006; 16: 949-953. 
[17] Nejatzadeh-Barandozi F. Antibacterial activities and antioxidant capacity of Aloe vera. Org Med Chem Lett. 2013; 3: 5 .

[18] Hashemi SA, Madani SA, Abediankenari S. The review on properties of Aloe vera in healing of cutaneous wounds. Biomed Res Int. 2015; 1-6.

[19] Boudreau MD, Beland FA. An evaluation of the biological and toxicological properties of Aloe Barbadensis (miller), Aloe vera. J Environ Sci Health Part C. 2006; 24: 103-154.

[20] Harlev E, Nevo E, Lansky E, Ofir R, Bishayee A. Anticancer potential of aloes: antioxidant, antiproliferative, and immunostimulatory attributes. Planta Med. 2012; 78: 843-852.

[21] Surjushe A, Vasani R, Saple D. Aloe vera: a short review. Indian J Dermatol. 2008; 53: 163-166.

[22] Sahu PK, Giri DD, Singh R, et al. Therapeutic and medicinal uses of Aloe vera: a review. Pharmacol Amp Pharm. 2013; 4: 599-610.

[23] Gupta A, Rawat S. Clinical importance of Aloe vera: review. Res J Top Cosmet Sci. 2017; 8: 30-39.

[24] Rodrigues LLO, de Oliveira ACL, Tabrez S et al.Mutagenic, antioxidant and wound healing properties of Aloe vera. J Ethnopharmacol. 2018; 227: 191-197.

[25] Pub Med. Evaluation of antioxidant potential of Aloevera extract. Agric food chem. 2003; 17-51(26): 7788-91.

[26] Garde GK, Vagbhat S. Marathia translation of vagbhat's astangahridya. Uttarstana: Aryabhushana Mudranalaya. 1970; 40-48.

[27] Kamat JP, Boloor KK, Devasagayam TP, Venkatachalam SR. Antioxdant properties of Asparagus racemosus against damagedinduced by gamma radiation on rat liver mitochondria. J Ethanopharmacol. 2000; 71: 425-435.

[28] Acharya SR, Acharya NS, Bhangale JO, Shah SK, Pandya SS. Antioxidant and hepatoprotective action of Asparagus racemosus Willd. root extracts. Indian J Exp Biol. 2012; 50(11): 795-801.

[29] Velavan S., Nagulendran K., Mahesh R., In vitro antioxidant activity of Asparagus racemosus root, Pharmacog Mag., Jan.-March 2007; 3: 26-33.

[30] Muruganadan S, Garg H, Lal J, Chandra S \& Kumar D, Studies on the immunostimulant and antihepatotoxic activities of Asparagus racemosus root extract, J Medic Arom Plant Sci. 2000; 22: 9-52.

[31] Gautam M, Diwanay S, Gairola S, Shinde Y, Patki P, Patwardhan B. Immunoadjuvant potential of Asparagus racemosus aqueous extract in experimental system. J Ethnopharmacol. 2004; 91(2-3): 251-255.

[32] Fabiola, Dr. V. Judia Harriet Sumathy. A Study on Phytochemicals, Antioxidant, Antidiabetic and Antimicrobial Activity of the Leaves of Solanum Trilobatum. International Journal of Engineering and Techniques. Feb 2018; $4(1)$.

[33] Kumar SRS, Priya LC, Rao KVB. Pharmacologyonline. 2011; 3: 1336-1341.

[34] Kumar SRS, Sakthivel M, Karthik L, Mythili S, Sathiavelu A. Asi. J. Plant Sci. Res. 2011; 1(1): 48-56.

[35] Annamalai P, Khosa RL, Hemalatha S. Ira. J. Pharma. Res. 2009; 8(4): 269-273.

[36] Chinthana P, Ananthi TJ, Chem. Pharma. Res. 2012; 4(1): 72-74.

[37] Livingston RNR, Pooshan GV, Venkatachalam VV, Kumar MV. Pharmacologyonline. 2009; 3: 758-765.

[38] HR Smith; JW Heusel; IK Mehta; S Kim; BG Dorner; OV Naidenko; Proc Natl Acad Sci USA. 2002; 99: 8826-31.

[39] AK Meena, A Singh, P Panda, S Mishra, MM Rao. Tinospora cordifolia: its bioactivities \& evaluation of physicochemical properties, IJPPR. 2010; 2: 50-55.

[40] U Sharma, M Bala, N Kumar, B Singh, RK Munshi, S Bhalerao. Immunomodulatory active compounds from Tinospora cordifolia, J. Ethnopharmacol. 2012; 141: 918-926.

[41] HC Goel, J Prasad, S Singh, RK. Sagar, PK Agrawala, M Bala, AK Sinha, R Dogra. Radioprotective potential of an herbal extract of Tinospora cordifolia, J. Radiat. Res. 2004; 45: 61-68.

[42] VV Sonkamble, LH Kamble. Antidiabetic potential and identification of phytochemicals from Tinospora cordifolia, Am. J. Phytomed. Clin. Ther. 2015; 3: 97-110.

[43] K Sinha, NP Mishra, J Singh, SPS Khanuja. Tinospora cordifolia (Guduchi) a reservoir plant for therapeutic applications, Indian J. Tradit. Knowle. 2004; 3: 257-270.

[44] Bishayi B, Roychowdhury S, Ghosh S, Sengupta M, Hepatoprotective and immunomodulatory properties of Tinospora cordifolia in CCl4 intoxicated mature albino rats, J Toxicol Sci. 2002; 27: 139-146.

[45] A Kapil, S Sharma. Immunopotentiating compounds from Tinospora cordifolia, J. Ethnopharmacol. 1997; 58: 8995. 